\title{
Transforming from a cold war military heritage site into a new tourist destination: the case of Matsu Archipelago
}

\author{
C.-C. $\mathrm{Fu}$ \\ National Cheng Kung University, Taiwan
}

\begin{abstract}
The Matsu Archipelago, located northwest of the Taiwan Strait, is geographically adjacent to the Chinese Mainland and politically governed by the Taiwan Government. The unstable and uncertain era of the early 1950s included threats from Communist China to Taiwan. In the 1950s, Matsu began attract international attention during two Taiwan Strait Crises, in which guns and cannons from the Chinese Mainland blasted Kinmen and Matsu for weeks. Consequently, the Nationalist Government in Taiwan began to reinforce Matsu as a military stronghold even though the second crisis had already ended. The government constructed various types of military facilities to prevent potential invasion of the Chinese People's Liberation Army. The US government confirmed the role of Matsu Archipelago as a Pacific Ocean stronghold against communism during the Cold War when the Korea War broke out.

High-density military facilities and installations such as underground tunnels and strongholds have formed a special cultural landscape in Matsu. Beginning in the early 1990s, Matsu began to develop in a unique manner. First, on May 11, 1994 Matsu was removed from serving as a military frontline. Second, Matsu was designated as a national scenic area in 1999, and in 2009, the Taiwan government chose the military cultural landscape as a World Heritage potential site. When the War Zone Administration Committee of Matsu finally ended, Matsu returned to civilian administration operation. However, after cleaning up the environment, the people in Matsu realized that the frontline atmosphere echoed in the many nearby abandoned military installations is a precious resource for the islands. Hence, a new role for Matsu was envisioned in its interaction with both domestic and foreign tourists. This study investigates transformation of the island when increasingly more military forces are
\end{abstract}


withdrawn and presents a discussion of strategies for future sustainable tourism. Keywords: Matsu, cold war, military heritage.

\section{Introduction}

The Matsu Archipelago, consisting of 36 islands, is located northwest of the Taiwan Strait and is geographically adjacent to the Chinese Mainland. Because of its significant strategic location, the Archipelago has functioned as a military front by the Nationalist Government in Taiwan against Chinese Communism since 1949. When the Nationalist Government governed Taiwan in the early 1950s, threats from Communist China still existed. The Central Intelligence Agency of the United States reported to the US president that "the fall of Taiwan before the end of 1950 still seems the most likely course of future development." On January 5, 1950 President Harry Truman announced that the United States will not get involved in the dispute of the Taiwan Strait, which meant that United States would not intervene if the Chinese Communists were to attack Taiwan [1]. However, when the Korean War broke out on June 25 1950, US support for Taiwan became a firm policy. President Truman reacted by declaring the "neutralization of the Straits of Formosa" on June 27. The Seventh Fleet was sent into the Straits under orders to prevent any attack on Taiwan. From that point on, Taiwan was placed under US military protection. Given the support of the United States, President Chiang Kai-shek of the Nationalist Government in Taiwan ordered fortification of Kinmen (Quemoy) and Matsu as bases for his reconquest of China. Numerous Nationalist troops moved to the islands, and both times the United States responded with military support [2].

Matsu became the focus of the First Taiwan Strait Crisis in the 1950s (August 11, 1954 - May 1, 1955) and the Second Taiwan Strait Crisis (August 23, 1958 January 1, 1959). In both crises, guns and cannons from the Chinese Mainland blasted Kinmen and Matsu for weeks. Consequently, the Nationalist Government in Taiwan began to reinforce Matsu as a military stronghold even though the crisis had already ended. The government constructed various types of military facilities to prevent the invasion of the Chinese People's Liberation Army. Beginning in 1956, a special administration system was set up. The War Zone Administration Committee integrated military and civil affairs, and the daily life of Matsu inhabitants was confined by military considerations.

During the 1960 US presidential election debates, candidates Richard Nixon and John F. Kenney pledged to use US forces if necessary to protect the Taiwan from invasion by the Communist China, which the US did not at that time recognize as a legitimate government [3]. Vice President Nixon stressed that, because Kinmen and Matsu were in the "area of freedom," they should not be surrendered to the Communists as a matter of "principle." The US government affirmed the role of the islands as a Pacific Ocean stronghold against Communism during the Cold War [4].

Recognizing the international trends and considering the political development in Taiwan, martial law, enacted since 1949, was lifted on July 15, 
1987 followed by termination of "Temporary Provisions effective during the Period of Communist Rebellion "on April 30, 1991. However, martial law remained in Kinmen and Matsu until November 7, 1992 with the inauguration of a new civilian magistrate. When entry and exit control was finally lifted on May 11,1994 , a new role for Matsu was envisioned regarding its interaction with both domestic and foreign tourists. This study investigates the development of the Matsu Archipelago islands from a Cold War heritage site to a tourist attraction and presents the argument that the military cultural landscape of Matsu provides endless resources for future cultural tourism [5].

\section{Military heritage in Matsu}

Military facilities in Matsu can be categorized into five types, namely coastal defensive facilities (strongholds), barracks, underground tunnels, village watchposts and military-related civil facilities. Each type may include built structure, signs, slogans, murals, weapons and their specific sites. Military facilities in Matsu are unique because of their various functions, incomparable scales and difficult constructions shown by some examples of underground tunnels and combat villages.

\subsection{Underground tunnels}

Underground tunnels are the most idiosyncratic among various military facilities in Matsu. They are invisible from the ground and dug deeply into rocks. Certain researches indicate that Matsu tops the world in underground tunnel density with its mere 36 square kilometers of land. These tunnels are linear facilities connecting different strongholds and have defensive, transportation and storage functions. The topography of Matsu and the geologic characteristics of granite offer the best condition for tunnel construction. Construction difficulty was overcome primarily by thousands of soldiers working numerous days, using nothing more than simple hand tools. Many soldiers died during the construction (Figure 1).

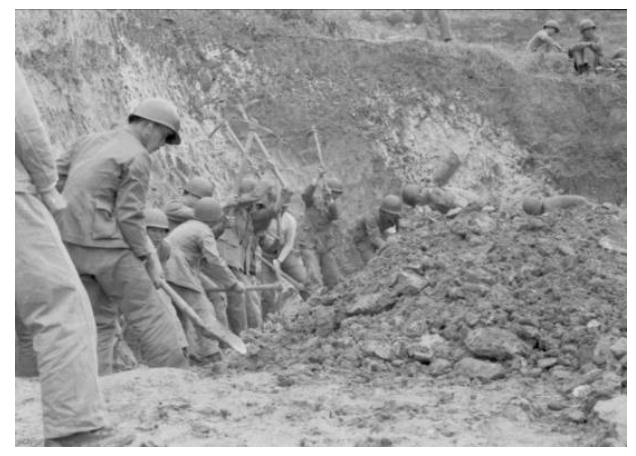

Figure 1: Soldiers using hand tools to dig the tunnel during the Cold War period in Matsu. 
In 1968, the Beihai Tunnel (North Sea Tunnel) Project began constructing tunnels in Nangan, Beigan, Cicyu, and Dongyin to anchor small landing craft. Beihai Tunnel in Nangan is located near the Renai Village and runs from the Tieban Coast deep into the hills. Dug through the granite hills interior, the tunnel is 18 meters in height and 10 meters in width and is shaped like a Chinese character jing (well). The total walking trail of 700 meters takes 30 minutes to walk, which is only possible when the tide is low. The tunnel connects to the ocean, and is capable of safely protecting approximately 100 small landing craft from bad weather and the eyes of the enemy. Certain scholars consider it an incomparable military installation in the world. A giant screen wall with four Chinese characters quifu shengong (ghost axes and god skill) was erected in front of the present entrance to emphasize the superlative craftsmanship and construction achievement of the soldiers. Statues of soldiers digging the tunnel were erected in 1990 to commemorate the construction (Figure 2).

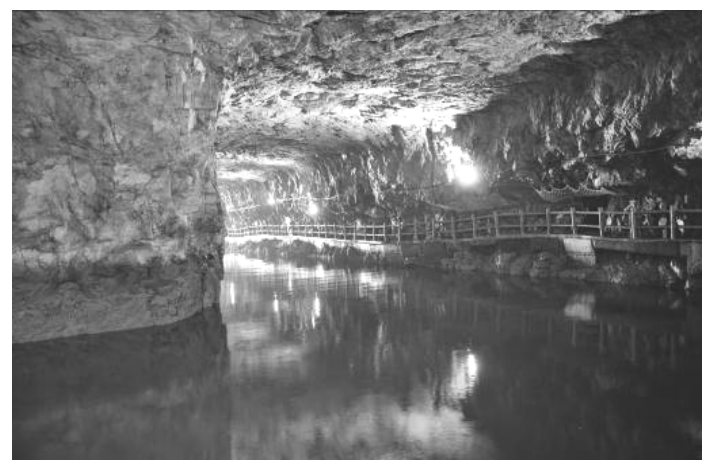

Figure 2: Water trail of the Beihai Tunnel in Nangan, Matsu.

In addition to the Beihai Tunnel in Nangan, two more tunnels with the same name were built at the same time in Beigan and Dongyin. Beihai Tunnel in Beigan, also called Wusha Tunnel, or Wusha Beihai Tunnel, is 550 meters long and 9 to 15 meters wide. Although it is smaller in scale than its Nangan counterpart, the Beihai Tunnel in Beigan was also dug laboriously out of solid granite by soldiers using simple tools. The Beihai Tunnel in Dongyin was built for the same purpose, measuring 193 meters long, 10 meters wide, and 12 meters high. Andong Tunnel in Dongyin is also a remarkable military achievement. The tunnel cuts directly through to Erchong Mountain, site of Matsu military headquarters. From the entrance, the tunnel slopes downward at a 30 degree angle along 464 steps that run 641 meters. Constructed in the 1970s, the tunnel functioned as a temporary war preparation assembly place. Spaces required for war operation, including arsenals, military barracks, a meeting hall, and a pigsty, are provided inside the tunnel. As a result, the spatial layout of the tunnel is much complicated than that of other tunnels in Matsu. 
Tie-bao (Iron Fort), also located in Nangan, is an individual coral stone projecting into the sea. The fort was originally the training base for special amphibious forces (frogman units). The fort location serves as a natural barrier to protect the bay. Because of its strategic location, Iron Fort was developed into a defensive post. The top of the land was dug out and hollowed. Concrete was poured to make it a fort and painted with camouflage colors. To prevent Chinese Mainland soldiers from landing, Iron Fort was covered with glass chips and iron bars. The fort includes stone dormitories, toilets and a kitchen and is equipped with facilities such as machine guns and guarding posts. The only army dog in Matsu that actually carried military rank was stationed here. Although the soldiers are gone, the renovated Iron Fort continues to exude a battleground aura. The Dongyin fort, Yi-hsien-tien, which literally means "a thread of sky" is one of the most spectacular defensive strongholds in Matsu and is hidden inside two steep cliffs with a narrow line of sky above and the sea below. A bridge, hanging dozens of meters above the sea, connects two sections of the stronghold, providing a place where the sound of swashing waves pounding against the rocks can be heard (Figure 3).

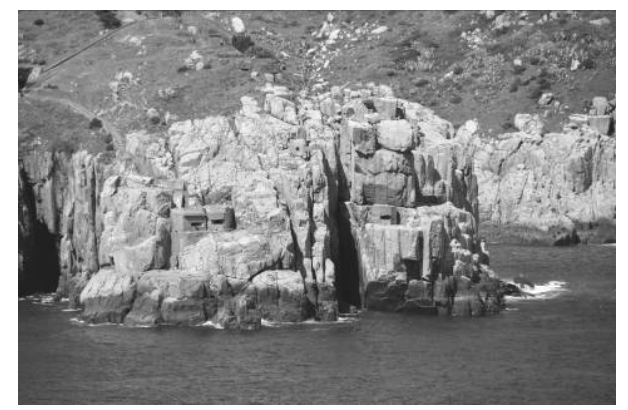

Figure 3: Yi-Hsien Tien, the most spectacular defensive stronghold in Matsu.

\subsection{Combat villages}

Matsu is famous for traditional settlements composed of residential houses and temples. Compared to Minnan (Southern Fujian) houses, which are most common in Taiwan and Kinmen areas, Matsu houses have high and small windows in responsive to the severe weather in winter. The exterior structure is mainly stone because of defensive considerations. The interior structure is composed of wood and heavy stones placed on the top of the roof tiles for the conveniences of the future replacement. Three villages, namely Cinbi, Jinsha and Dapu, are listed as "settlements" and protected by Taiwan Cultural Property Law. Houses in these settlements best illustrate regional characteristics (Figure 4). 


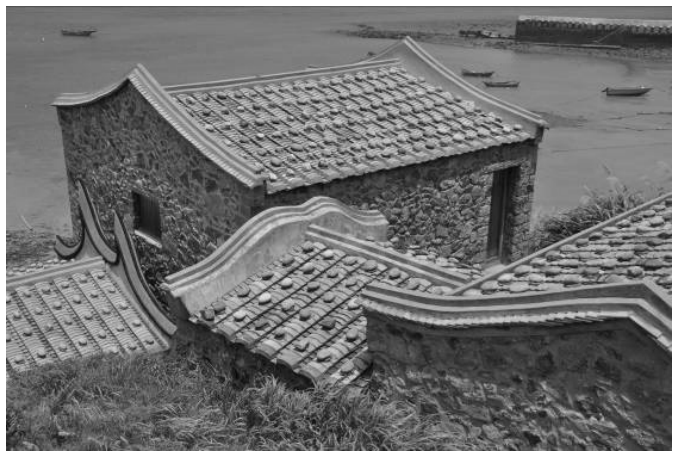

Figure 4: Dapu settlement, Juguan.

Although the beauty and uniqueness of Matsu houses are highly appreciated, people should not conclude that traditional settlements are unrelated to any military function. During the War Zone Administration period, every village in Matsu played a role as a combat village supervised by the War Zone Administration. Several features distinguish Matsu combat villages from normal villages. First, living with soldiers was an unforgettable experience for every villager in Matsu because the boundary between the War Zone and the Non-War Zone did not exist. Soldier presence was everywhere in the villages (Figure 5). Second, the lives of villagers were controlled and restricted. Curfew and light control were the two most influential actions. In these villages, curfew was enforced at nightfall. People needed a password to go out at night. Although the enforced time was later shortened, it caused considerable inconvenience among villagers. No light was allowed to emit from any house to avoid becoming a bombing target. To achieve this goal, households were required to close doors and windows at night and use light shades on all lighting equipment. Any emitting light resulted in warning or penalty.

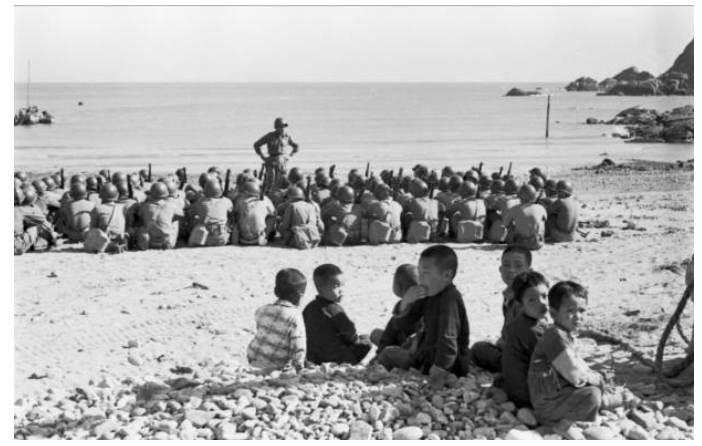

Figure 5: Living with soldiers was a normal life experience for villagers in Matsu (archive photos). 
Third, every villager was assigned a certain mission and a village militia was organized. The Matsu militia developed from the old "soldier/farmer dual character" idea and was organized as a self-defense force during the war. Among various units, the female unit was the most famous one. Fourth, the fear of war and death was ubiquitous among villagers. For example, bombing frequently occurred in the region. Fear and panic filled the entire archipelago at the sound of cannon fire. The Matsu coast was covered with land mines as a measure against sneak attacks, but innocent villagers often triggered the fatal instruments and became disabled. Fear of death often caused traumas to villagers.

Finally, patriotic, military and political signs, slogans, and murals were erected throughout all the villages. For example, vertical tablets with Chinese characters decorated on the walls of many houses. In most cases, the contents of these characters literally mean "be on your toes," "dedication and sacrifice", "save the compatriots in the Chinese Mainland", "long live president Chiang Kai-shek," "eradicate Chu and Mao the traitors," "anti-Communism and against Russia," "struggling for the final victory," "discipline and efficiency," and "sleep with your rifle as your pillow," etc. (Figures 6-7).Statues and portraits of national leaders, particularly Late President Chiang Kai-shek, can also be seen around the islands. ( Figure 8) Certain air-raid shelters, a special type of building in these villages, were decorated with a badge representing the American military, evidence of US involvement in this region during the Cold War period. The war zone installation and atmosphere distinguished Matsu settlements from their counterparts in other areas (Figure 9).

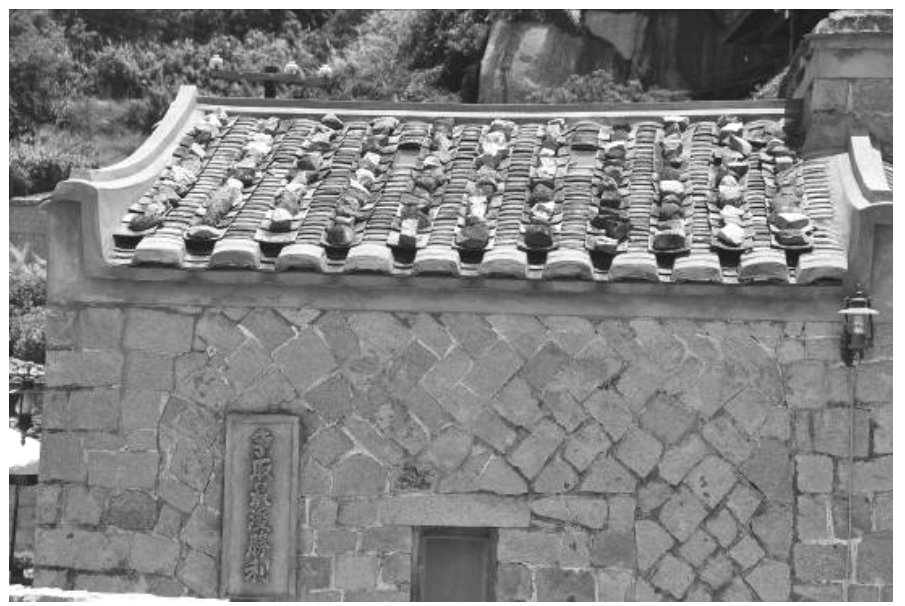

Figure 6: Military slogan on the wall of Matsu house. 


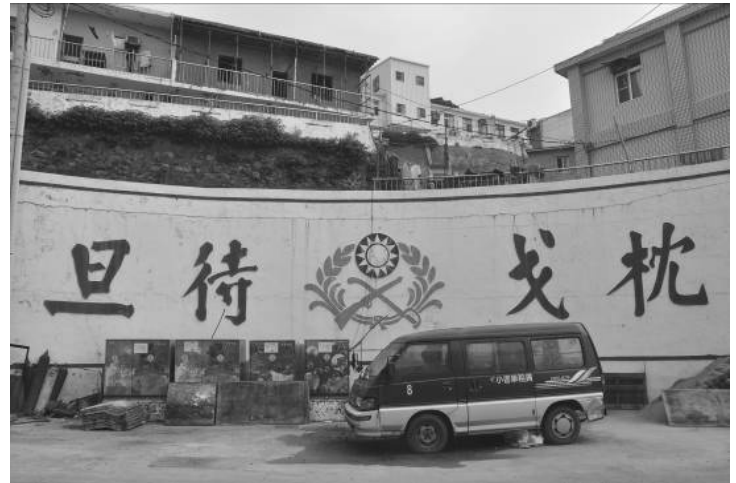

Figure 7: $\quad$ Military slogan at the entrance to a Matsu village.

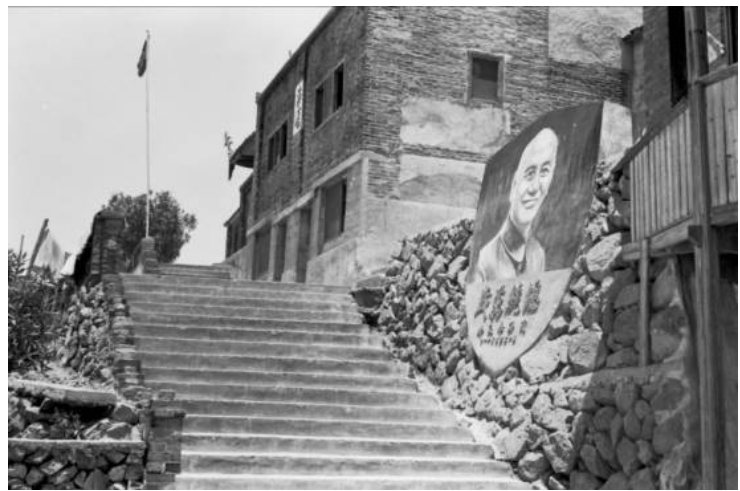

Figure 8: $\quad$ Portraits of Late President Chiang Kai-shek can be seen on every island (archive photo).

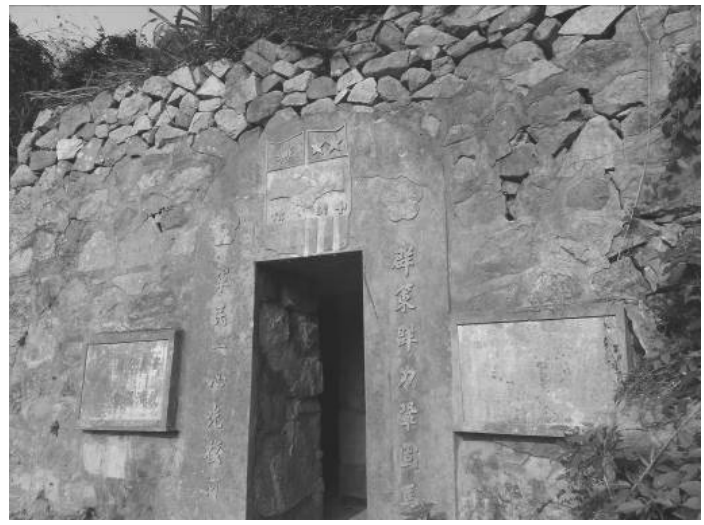

Figure 9: $\quad$ Air-raid shelter in a Matsu village. 
Folk temples are centers of Matsu religious activities. Many of them are equipped with "fire-sealing walls" that are exaggerated and shaped to resemble burning fire. These walls prevent fire from spreading. However, the most significant phenomenon of Matsu temples is that they were constructed with the help of the army, both in labor and financial support. As a result, many wooden tablets hanging in these temples were presented by the high-ranking army officers and commanders to commemorate the temple dedication. A tablet with characters fukuo yomin, which literally means "protect the country and safeguard the people," is the most common one in Matsu (Figure 10).

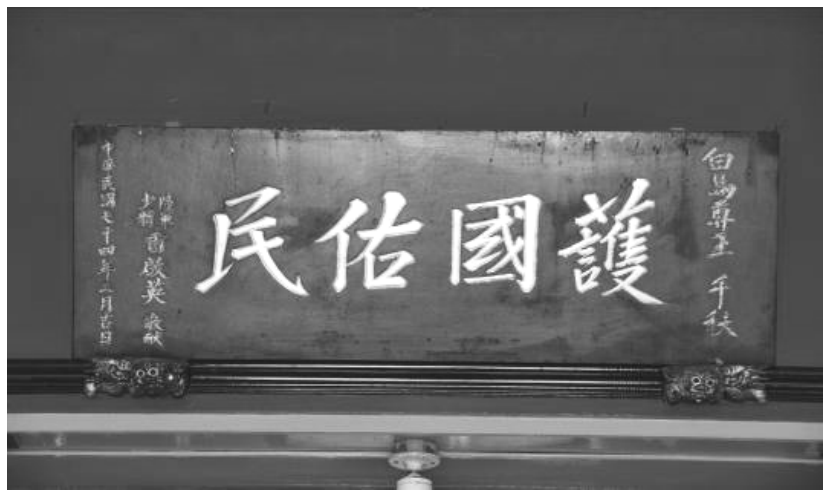

Figure 10: Tablet presented by an army commander in a Matsu temple.

\section{Three steps towards a new tourist destination}

After the designation of the Matsu Archipelago as a military front was lifted, the War Zone Administration Committee of Matsu ended and Matsu resumed operation under a normal civilian administration. Since then, tourism has been considered as the best direction for development. To achieve this goal, the government has undertaken three crucial steps. The first step is establishing the Matsu National Scenic Area. Recognizing the tourism potential, the Matsu National Scenic Area was approved by the Taiwan Government in 1993 one year after the dismissal of the Matsu military mission in 1992. The administration for this National Scenic Area was formally established in 1999. The mission of the administration includes developing and managing scenic and recreational spots, safeguarding tourists order and safety management, and business operation related to the scenic area. Matsu has since become an important entity in Taiwan tourist and cultural activities.

The second step is forming of the Beigan War Peace Memorial Park. The park originated in June 2002 when parliament passed a law to establish military museums in both the Kinmen and Matsu areas. In 2003, the Bureau of Tourism negotiated with the military authority to reuse the vacant Daao Military Camp as the site for the Park. Beginning in 2004, the Matsu National Scenic Area 
Administration has spent millions of dollars for the first phase construction such as the 06 Post and Exhibition Hall. The Hall was officially opened by the vice president. The main objective of the Park is to become a miniature Matsu in military history, war knowledge and military battlefields, so visitors can experience the war front atmosphere. Consequently, significant military values have been added to tourist considerations. Beginning in 2006, the Matsu National Scenic Area Administration has planned and managed the War Peace Memorial Park. Equipped with authentic weapons and military vehicles in a real military field, the Park has gradually developed into a setting with both educational and recreational functions. After becoming an open-air museum, the transformation of War Peace Memorial Park from a military heritage to a new tourist attraction has been completed and the Park has assumed new social meaning [6] (Figure 11).

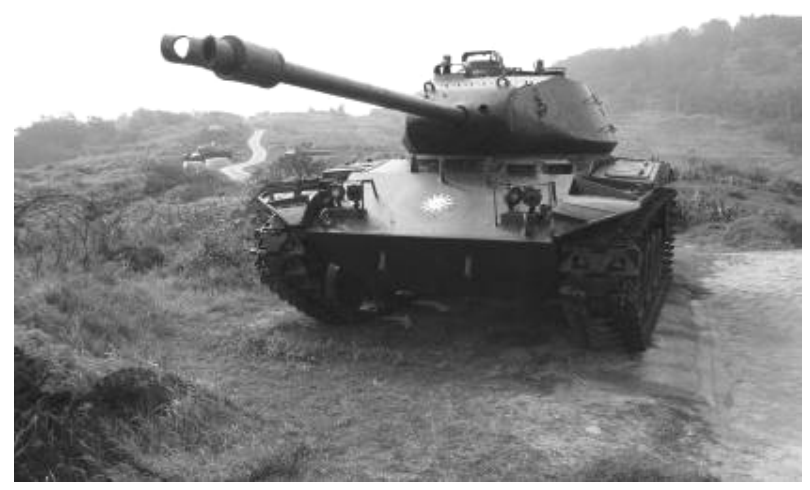

Figure 11: Open air exhibition at War Peace Memorial Park in Beigan.

The third step is the action by the Council for Cultural Affairs (CCA) to list Matsu as a World Heritage potential site in Taiwan. The government of Taiwan has promoted World Heritage participation since 2002. The CCA World Heritage Promotion Committee chose twelve locations as so-called potential site. In 2009, the committee was re-organized and added five sites to the list of potential sites, and expanded Kinmen Island to include Matsu's military heritage, changing the name to Kinmen-Matsu Military Cultural Site. In 2010, Matsu Battlefield cultural landscape became an individual potential site.

The CCA action manifests the military heritage of Matsu as possessing "outstanding universal value" required by the World Heritage criteria. The value of Matsu military heritage has been studied and compared with the Berlin Wall in Germany, the Panmunjeom between North and South Korea, and the $\mathrm{Cu} \mathrm{Chi}$ Tunnel in Vietnam. The three sites have been evaluated and categorized as possessing military heritage with historical values to witness the post-war Cold War development. Reviewing Matsu military heritage in this global context could identify its role as an important Cold War reference and highly recognize 
its universal value, because Matsu military heritage as a whole is much denser than in any country [7].

\section{Cooperation between different sectors}

Although local villagers profited from selling foods and goods to army and associated staffs during the military occupation period, tension exists between local residents and the army because private lands were claimed for military use and local activities were restricted. However, future planning of Matsu Archipelago as a sustainable tourist attraction will transform tension into cooperation. The success and sustainability of tourist development depends on a close cooperation between public sectors and local people. In response to the recognition of the 1999 International Charter on Cultural Tourism and the 2011 Paris Declaration on Heritage as a driver of development that the relationship between heritage places and tourism is dynamic. It may involve conflicting values and should be managed in a sustainable way for present and future generations, local leaders from different communities are trained and educated with heritage knowledge with an expectation that they might played an important role in tourist development. Self-awareness for many villagers has emerged and NGO organizations have become involved in conserving military heritage. Scholars from various disciplines are assisting Matsu authority to survey, investigate and research strategies for future tourism [8]. For example, this author has presented Matsu research results in different international conferences since 2010 to raise awareness of Matsu military heritage, to international audiences and to construct a platform for dialogue among different sectors.

\section{Conclusion}

Before terminating military administration, Matsu formed a frontline for Taiwan government to resist the possible attack from Chinese mainland troops. Communication with other parts of Taiwan and the world was restricted. Under such a circumstance, normal development halted and all establishments became military-oriented. When martial law ended and the islands opened their doors in 1992, formerly inaccessible military facilities such as watch-posts, barracks and tunnels faced a new destiny. Military presence in Matsu has decreased dramatically the last few decades, followed by a push to make the islands more of a tourist destination. In the first issue of Lonely Planet's Chinese edition journal published in September 2011, Matsu was selected as the best tourist attraction and first destination of Taiwan. This fact illustrates the significance of Matsu and its potential.

\section{References}

[1] Garver, John W., The Sino-American Alliance- National China and American Cold War Strategy in Asia. Armonk, N.Y.: M.E.Sharpe, 1997. 
[2] Lasater, Martin, The Security of Taiwan: Unraveling the Dilemma. Washington D.C.: Georgetown University, 1982.

[3] Szonyi, Michael, Cold War Island. Cambridge: Cambridge University Press, 2008.

[4] Ball, S.J., The Cold War - An International History 1947-1991. London: Arnold, 2001.

[5] Longstreth, R. (ed.), Cultural Landscapes. Minneapolis: University of Minnesota Press, 2008.

[6] Fu, Chao-Ching, 'New Social Meaning and Heritage Significance for the Military Cultural Landscapes in Matsu', Heritage $2010-2^{\text {nd }}$ International Conference on Heritage and Sustainable Development, Jun 22-26, Evora, Portugal, 2010.

[7] Fu, Chao-Ching, 'From a Military Front to a Cold War Heritage Site - A study of the prospect of Matsu Archipelago as sustainable tourism islands', ICOMOS $17^{\text {th }}$ General Assembly Scientific Symposium, November 27- December 2, Paris UNESCO, 2011.

[8] Rojek, Chris and John Urry, Touring Cultures - Transformation of travel and Theory. London: Routledge, 1997. 